\title{
Pembelajaran E-Learning Berbasis Web Bagi Pengajar untuk Mendukung Kegiatan Perkuliahan di Politeknik Negeri Padang
}

\section{Learning Web-Based E-Learning for Educators to Support The Academic Activities In Padang State Polytechnic}

\author{
Maimuzar $^{1)} \&$ Nasrul $^{2)}$ \\ ${ }^{1)}$ Jurusan Teknik Mesin Politeknik Negeri Padang Kampus Limau Manis Padang 25163 \\ Telp 0751-72590 Fax 0752-72576 Email: maimuzar@yahoo.com \\ ${ }^{2)}$ Jurusan Teknik Elektro Politeknik Negeri Padang Kampus Limau Manis Padang 25163 \\ Telp 0751-72590 Fax 0752-72576 Email: nasrulnawi@yahoo.com
}

\begin{abstract}
We-based e-Learning System can be used to support lecture's activity. Lecturer as a teacher need a servise of the Sistim which suitable for their activities. Lecturer's activities consist of delivering materials, discussion and interaction with their students. Because of that the aplication design is needed to support the activities of lectures.

Designing the web based e-Learning System is intended to give a service on the lecture. Lecture can do their teaching activities, delivering the materials and administering it using this e-Learning aplication. From the student side, they have to receive the materials easily from anywhere at anytime. This research have an objective to design a web based e_learning System which give an adequate service supporting the lecturer's activities. Lecture can use this aplication ti deliver their materials, communicating and interacting with their student, observing the progress of students and give result of learning evaluation from the web.

The design and implementation of this e-learning application is based on the requirement of the users. The users consist of lecturer, student, quest, and administrator. The process of aplication design is built within Sistimatical stages. After finishing the design process, the aplication is implemented on the real Sistim. Doing the design testing and functional is to test if the aplication can go well together with design and funtionality.

e-Learnign aplication that has been built is designed based on lecturer's need when doing their lecture's activities. This e-Learning aplication can be used as contribution for building new aplication or5 improving others that has already exist.
\end{abstract}

Keywords: e-Learning, We-based

\section{PENDAHULUAN}

Didalam sistem pendidikan tradisional, interaksi antar pengajar dan pelajar terjadi saat kedua belah pihak bertatap muka dan pada proses ini terjadi penyampaian informasi dan bahan ajar dari pengajar kepada pelajarnya. Dengan penerapan sistim pengajaran berbasiskan teknologi informasi ini sedapat mungkin melengkapi atau bahkan menggantikan unsur-unsur yang ada dalam sistim pendidikan tradisional (tujuan, materi, metode, alat, dan penilaian), sehingga arus informasi tetap mengalir dari pengajar kepada pelajar setiap waktu tanpa ada batasan waktu dan tempat.
Sistim pembelajaran jarak jauh (distance learning) yang telah diterapkan dengan menafaatkan teknologi informasi melalui internet salah satunya adalah pembelajaran berbasis web (web based distance lerning). Sistim ini merupakan media perantara pengajar dan pelajar dalam menyampaikan dan menjelaskan proses belajar mengajar tanpa harus langsung bertatap muka dengan pelajar, tetapi cukup dengan mengirimkan web. Begitu juga dengan pelajar, pelajar tidak harus menghadiri suatu pertemuan atau tatap muka dengan dosen untuk mendapatkan bahan ajar, tetapi dengan cara mengakses web yang didalamnya terdapat bahan ajar yang telah dikirimkan oleh pengajar. 
Gambaran mengenai interaksi antara pengajar dan pelajar melalui internet digambarkan pada gambar 1 .

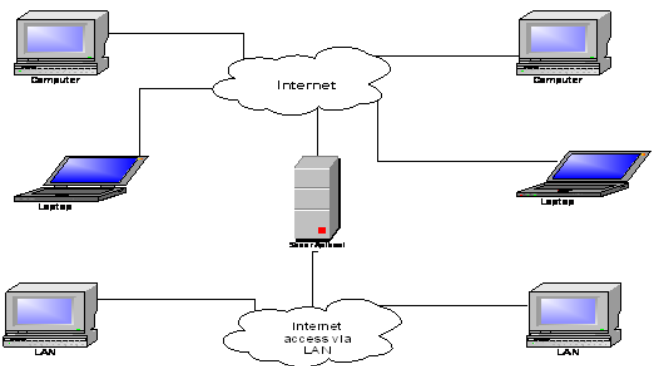

Gambar 1. Interaksi Belajar Mengajar melalui internet

Sistim yang mendukung aktivitas belajar mengajar harus mampu membantu pengajar dan pelajar untuk mencapai tujuan pengajaran. Pelajar bisa mendapatkan bahan ajar dengan mudah jika bahan tersebut mudah diakses dan telah tersedia didalam web. Dilain pihak, pengajar sebagai penyedia bahan ajar harus mempersiapkan, menyediakan serta menyajikan bahan ajar dalam web sehingga terjadi interaksi belajar mengajar dengan pelajar. Pengajar haruslah dapat menggunakan sistim tersebut dengan berbagai layanan dan kemudahan untuk melakukan aktivitasnya.

Didalam aktivitas perkuliahan, dosen melakukan proses pembelajran bersama dengan mahsiswa. Bagi dosen, Sistim $e$ learning haruslah dapat memberikan layanan untuk mendukung aktivitas perkuliahan serta berinteraksi dengan mahasiswanya. Dosen juga harus dapat melakukan administrasi perkuliahan dan memantau aktivitas mahasiswa melalui Sistim tersebut. Berdasarkan pada gambaran tersebut timbul suatu pertanyaan Sistim seperti apakah yang dapat mendukung kegiatan belajar mengajar yang dapat mendukung dosen untuk melakukan aktivitasnya dengan baik. Aplikasi dan layanan yang harus diberikan oleh sistem untuk memenuhi kebutuhan pengajar. Oleh karena itu perancangan Sistim e-learning harus dapat mendukung dosen dan memberikan layanan yang dapat memenuhi kebutuhan dosen dalam proses pembelajaran.

\section{Tujuan Penelitian}

Tujuan penelitian sistim e-learning bagi dosen ini adalah :

1. Merancang Sistim e-learning yang dapat memfasilitasi kebutuhan pengajar dalam proses pengajaran.

2. Memberikan masukan perancangan sistim e-learning bagi pembangunan dan perbaikan sistim e-learning yang telah ada maupun yang hendak dibangun.

\section{Perumusan Masalah}

Dosen sebagai salah satu pengguna sistim e-learning membutuhkan layanan sistim untuk mendukung aktivitasnya didalam proses pembelajaran. Aktivitas dosen terdiri dari: penyampaian bahan ajar kerpada mahasiswa, diskusi dan interaksi dengan mahsiswa, evaluasii perkuliahan seperti tugas dan tes, serta melakukan evaluasi terhadap kegiatan mahasiswa sehubungan dengan bahan ajar yang diajarkan. Bahan ajar yang disampaikan kepada mahasiswa meliputi dokumen teks, prersentasi, multimedia audio dan video yang disampaikan melalui sistim. Layanan sistim e-learning yang dibuat berupa aplikasi yang sesuai dengan aktivitas dosen dalam proses pembelajaran

\section{Pembatasan Masalah}

Penelitian tesis ini dibatasi terutama pada perancangan sistim pembuatan protype. Perancangan sistim dilakukan berdasarkan metode pembelajaran jarak jauh dengan menggunakan teknologi pendukung yang sudah ada. Sedangkan pembuatan prototype dilakukan berdasarkan desain Sistim yang dibuat.

\section{METODOLOGI}

Perancangan sistim e-learning ini dilakukan dalam lima tahap, yaitu :

1. Pendefinisian masalah yang akan dikaji dan dilanjutkan dengan studi literature melalui kajian pustaka mengenai 
konsep pembelajaran jarak jauh (distance learning).

2. Pengkajian terhadap kebutuhan pengajaran untuk melakukan aktivitas pengajaran melalui web dan analisis terhadap kebutuhan tersebur agar dapat diindefikasikan komponen-komponen dan layanan-layanan yang akan dibangun.

3. Pengkajian terhadap Sistim pendukung untuk mewujudkan Sistim.

\section{Kegunaan Hasil Perancangan}

Perancangan sistim e-learning bagi pelajar untuk mendukung kegiatan perkuliahan ini diharapkan memberikan manfaat :

1. Sistim e-learning ini digunakan oleh dosen dalam mendukung dan melakukan aktivitas belajar mengajar yang lebih mudah, cepat, dan fleksibel.

2. Memberikan kemudahan bagi mahasiswa untuk mendapatkan informasi dan bahan ajar melalui sisitem e-learning tanpa batasan jarak, ruang dan waktu.

\section{Sistem Pembelajaran Jarak Jauh}

Sistim pembelajaran jarak jauh merupakan suatu metode instruksional penyampaian bahan ajar untuk melakukan aktivitas belajar mengajar antara pengajar dengan pelajar tanpa dibatasi oleh jarak, waktu, dan tempat serta kesempatan belajar bagi semua golongan yang memenuhi persyaratan tertentu ${ }^{1}$. Proses pembelajaran yang terjadi dapat dijembatani dengan suatu media untuk melakukan aktivitas belajar mengajar. Oleh karenanya batasan yang dihadapi dapat dikurangi atau bahkan dihilangkan. Di dalam Sistim pembelajaran jarak jauh pada tingkat perguruan tinggi terdapat beberapa pelaku yang memungkinkan sistim berjalan. Pelakupelaku tersebut adalah dosen, mahasiswa, departemen, administrator, dan penyedia layanan.

\footnotetext{
${ }^{1}$ Distance Learning Resource Network, What is DIstance education?,

http://www.wlm.org/library/index.html
}

Mahasiswa dan dosen merupakan pihak-pihak yang melakukan aktivitas belajar mengajar didalam suatu departemen. Administrator merupakan pihak yang mengelola sistim, sedangkan penyedia layanan merupakan pihak yang memfasilitasi Sistim.

Pengertian belajar jarak jauh sering disamakan dengan pendidikan jarak jauh. Sebenarnya belajar jarak jauh merupakan hasil dari proses pendidikan jarak jauh. Pendidikan jarak jauh menekankan pada bagaimana suatu proses pengajaran dilakukan oleh pengajar dapat diterima oleh pelajar dengan baik tanpa terhalang oleh batasan jarak. Sedangkan belajar jarak jauh lebih menekankan kepada bagaimana seorang pelajar dapat belajar dengan baik tanpa batasan jarak dan waktu. ${ }^{2}$

Konsep pendidikan jarak jauh mempunyai perbedaaan dengan konsep pendidikan tradisional. Perbedaanperbedaannya terletak pada :

1. Perbedaan lokasi antara pengajar dan pelajar

2. Penggunaan teknologi seperti e-mail, web, video sebagai media untuk menyampaikan bahan pengajaran.

3. Ketersediaan komunikasi dua arah antara pengajar dan pelajar.

\section{Penggunaan Teknologi Pada Sistem Pembelajaran Jarak Jauh \\ Media yang digunakan dalam} menyelenggarakan pembelajaran jarak jauh tergantung pada metoda penyampaian materi atau bahan ajar. Teknologi korespondensi, audio, video, dan yang berbasis komputer sampai kepada penggunaan intranet. Internet merupakan teknologi yang digunakan sebagai media penyampaian informasi dan bahan pengajaran.

\section{Distance Learning Berbasis Web}

\footnotetext{
${ }^{2}$ Enginerring Outreach, Distance Education at a Glance, http://www.uidaho.edu/eo/index/html.
} 
Pada sistim pembelajaran jarak jauh berbasis web (Web Based Distance Learning) penyampaian bahan ajar dilakukan melalui media elektronik yaitu web browser. Web server digunakan untuk menyampaikan materi yang diakses melalui web browser. Komunikasi dengan media tersebeut dilakukan dengan protocol TCP/IP (Transmission Control Protocol/Internet Protocol) dengan HTTP (Hyper Text Transfer Protocil). TCP/IP digunakan sebagai protokol komunikasi untuk menghubungkan komputer host ke internet, sedangkan HTTP merupakan protocol yang digunakan pada World Wide Web yang menentukan protokol format data, cara transmisinya, aksi web server, web browser untuk merespon berbagai perintah yang diterima.

Berdasarkan metode penyampaian tersebut dapat dibuat definisi pembelajaran jarak jauh berbasis web yaitu menyelenggarakan pembelajaran jarak jauh dengan aplikasi web. Aplikasi web tersebut dapat digunakan dalam metode Synchronous dan Asynchronous. Fasilitasfasilitas berupa e-mail, discussion forums, video conferencing, dan live lecture yang dapat digunakan pengajar dan pelajar di dalam proses pembelajaran.

Web-based learning dapat diklarifikasikan berdasarkan level interaksinya dan media yang digunakan Web-Based learning tersebut adalah :

\section{Text and graphics web-based learning}

Teks dan grafik adalah bentuk paling sederhana dalam program Web-based learning. Pengajar hanya menyimpan materi-materi pengajaran di dalam web dan dapat mengaksesnya dengan mudah.

\section{Interaksive Web-based Learning}

Model Web-based learning seperti ini level interaksinya berada di atas model pertama. Selain teks dan grafik juga disimpan data audio dan video yang masih bersifat pasif.

\section{Interaksive Multimedia Web-based Learning}

Interaksi antar pengajar dan pelajar dilakukan dengan menggunakan teknologi multimedia secara real-time melalui streaming audio dan video, diskusi web interaktif, bahkan konferensi desktop audio dan video. Interaksi dan komunikasi antara keduanya dapat dilakukan dalam dua arah. Level interaksi pada model ini paling tinggi dan paling rumit implementasinya, namun model seperti ini yang diharapkan dapat mencakup semua kondisi belajar mengajar pada Sistim tradisional.

\section{Kelebihan dan Kekurangan Aplikasi Berbasis Web}

Aplikasi berbasis web mempunyai kelebihan-kelebihan, tetapi juga mempunyai kekurangan-kekurangan. Kelebihan aplikasi berbasis web antara lain:

1. Fleksibel, mudah diakses dan cukup nyaman digunakan.

2. Cross-platform, dimana pemakai cukup menggunakan web browser pada computer mereka tanpa harus menyesuaikan secara rumit.

3. Relative lebih murah dalam menjangkau pelajar, terutama jika dihitung dari jumlah waktu yang dihabiskan seorang pelajar unruk menuju tempat pelatihan dalam jarak yang jauh.

4. Materi yang up to date dapat disediakan secara rutin oleh pengajar atau administrator tanpa harus menunggu materi dating.

5. Menghemat waktu dan biaya perjalanan bagi pengajar maupun pelajar, karena sukup melalui web browser penyampaian dan akses materi dpat diperoleh.

Sedangkan kekurangan Sistim distance learning dibandingkan Sistim pembelajaran tradsional adalah :

1. Media telekomunikasi relative terbatas, utamanya bila pelajar menggunakan sarana internet umum dan ditambah dengan padatnya jalur pada jam sibuk. 
2. Hubungan antara manusia dalam hubungan sosial dan emosional tidak dapat digantikan dengan komputer.

3. Metode e-Learning yang digunakan saat ini relative statis, tetapi seiring dengan perkembangan dan penurunan biaya investasi teknologi informasi, kekurangan ini lambat laun akan teratasi

4. Tidak semua materi belajar dapat digantikan dengan computer. Seperti pendidikan pembentukan karakter yang tetap membutuhkan pelatih atau pengajar ditempat secara fisik.

\section{HASIL DAN PEMBAHASAN}

\section{Perancangan E-Learning Web Bagi Dosen}

Pada bagian ini akan diterangkan beberapa bagian perancanagn e-Learning berbasis web bagi dosen. Perancangan eLearning ini dibangun dengan menggabungkan fungsi web server dan database server dengan menggunakan script PHP. Web server berguna untuk menerima dan merespon request dari web browser klien. Request yang diterima dapat berupa permintaan penginputan data atau penampilan data. Data disimpan di dalam database server. PHP merupakan server side scripting yang berfungsi sebagai engine dan menterjemahkan serta mengeksekusi perintah-perintah PHP.

Seperti halnya pada perancangan web lainnya, perancangan e-Learning ini diawali dengan halaman utama. Dari halaman utama ini terdapat hyperlink yang menghubungkan dengan halaman lain di dalam perancangan. Di dalam bab ini akan di bahas perancangan yang terdapat pada halaman utama kemudian dilanjutkan pada perancangan yang terdapat pada halaman dosen. Alur perancangan akan dimulai dari halaman utama pada bagian registrasi kemudian dilanjutkan pada halaman login.

\section{Perancangan Halaman Utama}

Halaman utama merupakan halaman default aplikasi e-Learning. Pada halaman utama terdapat hyperlink yang menghubungkan ke halaman registrasi untuk menjadi anggota Sistim e-Learning, halaman informasi mengenai perancangan dan daftar catalog mata kuliah online yang tersedia di dalam Sistim.

Pada halaman utama dideklarasikan script PHP untuk memanggil file script PHP lainnya. File-file script tersebut untuk melengkapi perancangan pada halaman utama. Script luar yang digunakan adalah myconn.php yang berfungsi untuk koneksi ke dalam database. Untuk koneksi ke dalam database MySQL digunakan script ini dengan membuat suatu koneksi yang tetap ke dalam database.

$<$ ?php

// file: connectdb.php(php conect database)

\$db_username = "root";

\$db_hostname = "localhost";

\$db_password = "";

\$db_name = "eko";

\$linksvr = mysql_connect $\left(\$ d b \_h o s t n a m e\right.$,

\$db_username, \$db_password)

or die ("Tidak dapat berhubungan dengan database server");

\$linkdb = mysql_select_db $\left(\$ d b \_n a m e\right.$, \$linksvr)

or die ("Tidak dapat membuka database $<\mathrm{b}>$ \$db_name $</ \mathrm{b}>$.");

?>

Script PHP lain yang sering digunakan pada halaman lainnya adalah script-script fungsi. Script tersebut adalah direktori.php, sql.php, dan waktu.php. Script direktori.php berfungsi untuk penanganan pembuatan drektori, pindah ke lain direktori, penghapusan direktori, melihat daftar direktori, mengubah nama direktori dan melihat isi dari sebuah direktori. Selain itu di dalam script tersebut juga terdapat juga fungsi penanganan pengupload-an file, pengupload-an file gambar pada berita serta menentukan jenis file. Pada file script waktu.php digunakan untuk menangani pencacatan waktu pengguna sejak mulai login sampai dengan logout. Sedangkan file script sql.php digunakan untuk menangani 
perintah-perintah SQL untuk mengakses database.

Terlihat pada gambar halaman utama aplikasi terdapat beberapa layanan aplikasi. Aplikasi-aplikasi ini disajikan pada halaman utama untuk memudahkan pengaksesan oleh pengguna serta mempercepat proses akses bagi pengguna. Pengguna dapat langsung pada tujuan tanpa harus membuka halaman lain untuk mendapatkan informasi mengenai berita, forum diskusi serta form login ke dalam sistim.

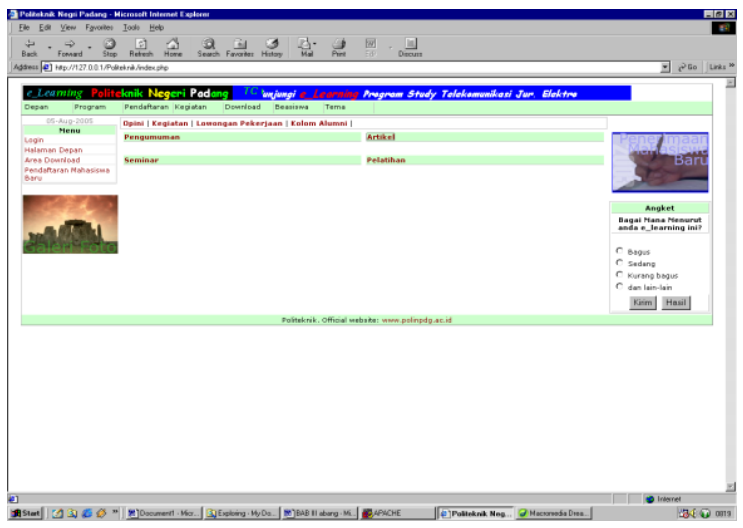

Gambar 2. Halaman Utama Sistem e-Learning Berbasis Web

\section{Registrasi Pengguna}

Form registrasi didapatkan dengan mengakses hyperlink Sign Up di bagian kanan atas halaman utama. Form registrasi digunakan untuk mendapatkan data-data mengenai : Nomor induk, nama, jalur pilihan, password, e-mail, tempat lahir, tanggal lahir, alamat, telepon, dan alamat libur. Data-data tersebut tidak harus diisikan semuanya oleh pendaftar. Datadata utama yang harus diinputkan adalah nomor induk, nama, password, dan e-mail. Data-data tersebut penting bagi verifikasi pengguna jika pengguna akan melakukan login ke dalam Sistim.

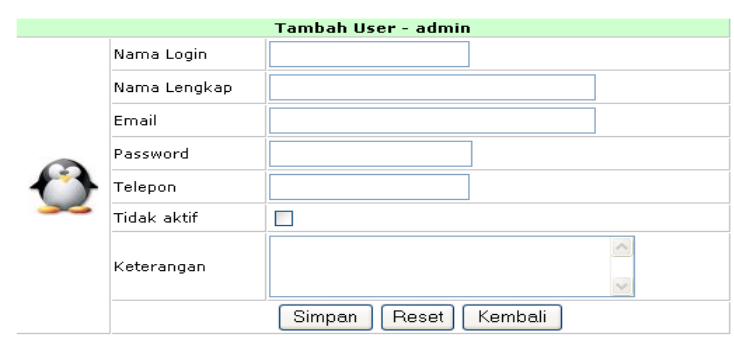

Gambar 3. Form Registrasi Sistem e-Learning

Pembedaan pengguna yang melakukan registrasi dilakukan pada panjang karakter nomor induk yang diinputkan. Bagi mahasiswa panjang karakater nomor induknya adalah delapan karakater, sedangkan untuk dosen, panjang karakter nomor induknya adalah sembilan karakter. Jika data-data sudah sesuai maka data akan dimasukkan ke dalam table.

\section{Login Pengguna Aplikasi}

Pada form login terdapat 2 input data yang harus dimasukkan oleh pengguna untuk mendapatkan akses ke dalam Sistim. Dua data yang diperlukan tersebut adalah nomor induk dan password. Nomor induk dan passwors tersebut akan dibandingkan dengan data yang terdapat di dalam database. Jika kedua data sesuai maka pengguna dapat mengakses Sistim sesuai dengan keanggotaan dan hak aksesnya. Pembedaan nomor induk dilakukan berdasarkan panjang karakter nomor induk pengguna. Bagi mahasiswa dibutuhkan delapan karakter, sedangkan dosen dibutuhkan sembilan buah karakter.

Semua entitas yang menggunakan Sistim ini harus melalui proses verifikasi melalui form login ini. Mahasiswa yang telah diverifikasi dan data yang diberikan sesuai serta status keanggotaannya satu atau aktif akan dibawa ke halaman mahasiswa. Bagi dosen dan admin juga dilakukan verifikasi.

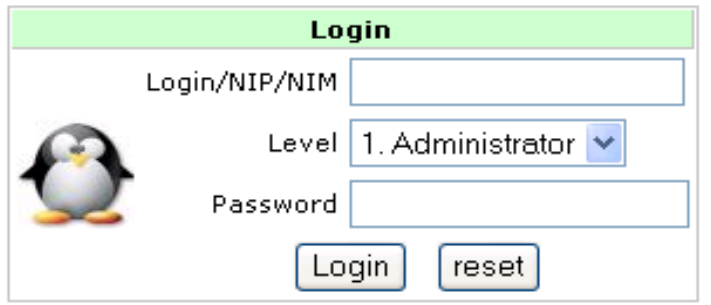

Gambar 4. Form Login Pengguna Aplikasi 


\section{Daftar Mata Kuliah Online}

Daftar mata kuliah yang terdaftar di dalam Sistim e-Learning akan ditampilkan di halaman course catalog. Daftar mata kuliah diambil dari table mata_kuliah yang mempunyai status satu atau aktif. Mata kuliah yang ada di dalam Sistim tetapi berstatus tidak aktif akan ditampilkan didalam course catalog. Pada halaman tersebut juga ditampilkan form pencarian mata kuliah untuk mempermudah pencarian mata kuliah yang didalam Sistim. $<$ ?

\section{If(\$act=="sorts")}

\$sql="select * from mata_kuliah

where status $=1$ order by $\$$ by";

Elseif(\$act=="search")

$\$$ sql='select * from mata_kuliah where \$katagori like ' $\%$ \$valu $\%$ ' and status $=1$ order by $\$$ kategori";

Else

\$sql='select $*$ from mata kuliah where status $=1$ ";

\section{If}

$\left(\right.$ ! $\left.\$ r s=m y s q 1 \_q i e r y(\$ s q 1, \$ m y c o n n)\right)\{$

return 0 ;

echo mysql_error();

\$coun=mysql_num_rows $(\$ r s) ;\}$ ?>

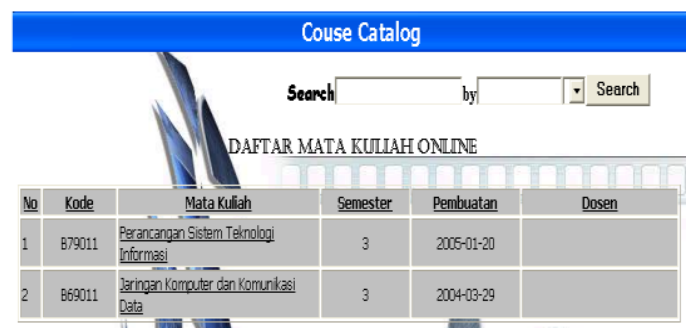

Gambar 5. Halaman Daftar Katalog Mata Kuliah

\section{Perancangan Dosen}

\section{Halaman Utama}

Bagi dosen yang telah terdaftar sebagai anggota Sistim e-Learning dapat mengakses halaman dosen. Setelah melakukan login dosen akan dibawa ke halaman utama dosen. Di dalam halaman dosen terdapat menu navigasi yang akan menghubungkan ke halaman lain untuk manajemen pengajaran dosen.

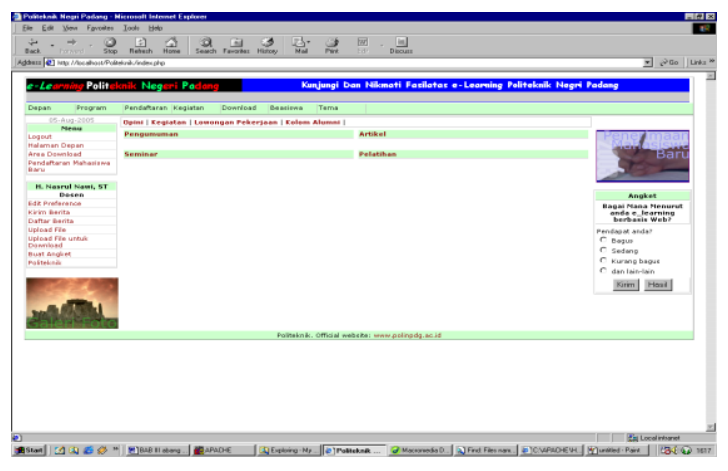

Gambar 6. Halaman Utama Pengajar

\section{Layanan Manajemen Mata Kuliah Registrasi Mata Kuliah Online}

Seorang dosen dapat meregistrasikan mata kuliah yang akan diajarkannya. Mata kuliah tersebut harus belum terdaftar dalam Sistim e-Learning. Mata kuliah yang didaftarkan oleh dosen akan dimiliki oleh dosen tersebut dan secara otomatis akan dikelola oleh dosen tersebut.

Pada form registrasi mata kuliah terdapat beberapa input data yang harus dimasukkan. Input data yang harus dimasukkan tersebut adalah kode mata kuliah, nama mata kuliah, jumlah kredit per semester mata kuliah, deskripsi mata kuliah, buku referensi, link referensidan status mata kuliah. Data-data tersebut akan dimasukkan ke dalam table mata_kuliah di dalam database.

Mata kuliah yang diregistrasikan akan dibuat direktori baru didalam Sistim. Direktori tersebut sesuai dengan kode mata kuliah. Di dalam direktori mata kuliah juga dibuat direktori Users, tugas dan quiz untuk menyimpan data tugas, quiz dan file mahasiswa.

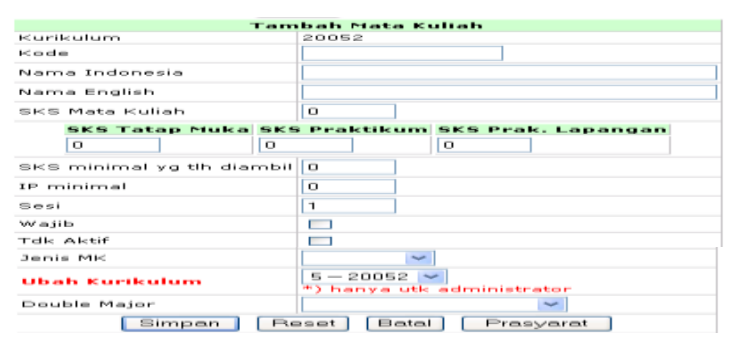

Gambar 7. Form Registrasi Mata Kuliah Baru 


\section{Manajemen Mata Kuliah Pengajar}

Mata kuliah yang telah diregistrasikan dapat dikelola oleh dosen yang memilikinya. Pengelolaan dilakukan untuk menyampaikan materi perkuliahan, tugas, quiz, serta penambahan akses bagi dosen lain. Dosen dapat mengakses deskripsi mata kuliah beserta informasi lainnya di dalam deskripsi mata kuliah.

Pada halaman deskripsi mata kuliah terdapat hyperlink ke halaman detail mata kuliah, tugas, quiz, dan daftar mahasiswa serta penambahan dan penghapusan hak akses pada dosen lain. Deskripsi singkat tentang mata kuliah ditampilkan untuk memudahkan pengelolaan mata kuliah. Dosen dapat mengakses halaman lain dengan memilih hyperlink dibagian atas deskripsi.

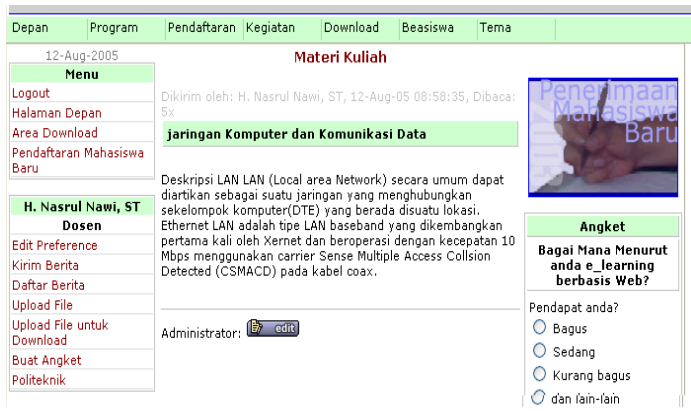

Gambar 8. Diskripsi Mata Kuliah

Pada halaman detail mata kuliah akan ditampilkan detail materi perkuliahan yang telah di upload ke dalam server. Penambahan materi kuliah dapat dilakukan pada halaman ini. Begitu juga pengeditan mata kuliah beserta status mata kuliah juga dapat dilakukan pada halaman detail ini. Materi-materi kuliah yang telah diupload juga dapat dihapus oleh dosen yang bersangkutan.

Pada materi perkuliahan terdapat modulmodul kuliah yang dibagi memjadi beberapa kategori. Modul kuliah dikategorikan menjadi bahan ajar yang merupakan file-file dokumen, bahan presentasi, file-file audio dan file-file video.

Penambahan hak akses mata kuliah dapat dilakukan oleh dosen yang memiliki suatu mata kuliah. Penambhan hak akses dimaksudkan untuk memudahkan dosen memberikan hak pengelolaan kepada dosen lain yang juga ikut mengajar mata kuliah tersebut. Jika tidak diperlukan dosen yang memiliki mata kuliah dapat menghapus hak akses yang telah diberikan.

\section{Manajemen Tugas dan Quiz Mata Kuliah}

Tugas dan quiz untuk suatu mata kuliah dapat diberikan oleh dosen pengajar. Tugas dan quiz tersebut dapat diakses melalui hyperlink yang terdapat pada halaman deskripsi mata kuliah. Halaman untuk tugas dan quiz diberikan pada halaman yang terpisah.

Pada halaman tugas akan ditampilkan daftar tugas yang diberikan oleh dosen yang bersangkutan. Untuk melihat informasi lengkap tugas tersebut, dosen dapat mengklik nama tugas. Dari nama tugas tersebut akan dihubungkan ke detail tugas yang dimaksud. Selain itu dosen juga dapat menambah tugas baru di dalam mata kuliah tersebut melalui hyperlink add tugas dibagian kiri atas daftar tugas. Untuk manajemen quiz, formatnya sama dengan tugas tetapi halamannya dibedakan.

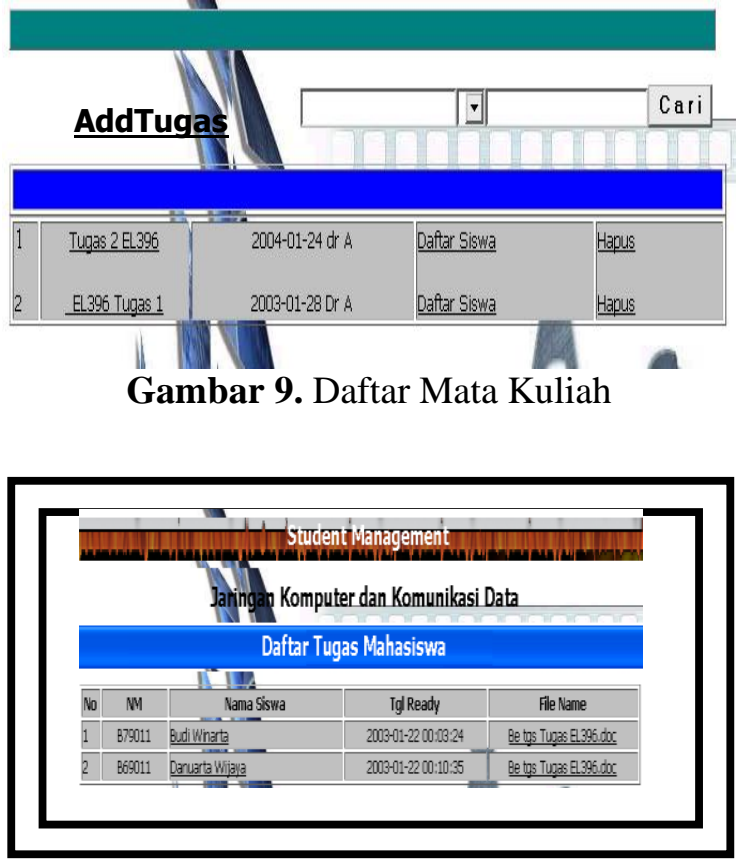

Gambar 10. Daftar Mahasiswa Pengumpul Tugas 


\section{Layanan Manajemen Pelajar}

Layanan lain yang diberikan pada Sistim e-Learning ini adalah layanan manajemen pelajar atau mahasiswa bagi dosen yang mempunyai suatu maya kuliah. Manajemen ini meliputi daftar mahasiswa yang mengikuti suatu mata kuliah, perkembangan mahasiswa, dan hasil evaluasi belajar mahasiswa. Semua layanan ini diberikan bagi dosen yang mempunyai suatu nata kuliah.

\section{Daftar Mahasiswa}

Daftar mahasiswa yang men gikuti suatu mata kuliah akan disajikan pada halaman managemen student.

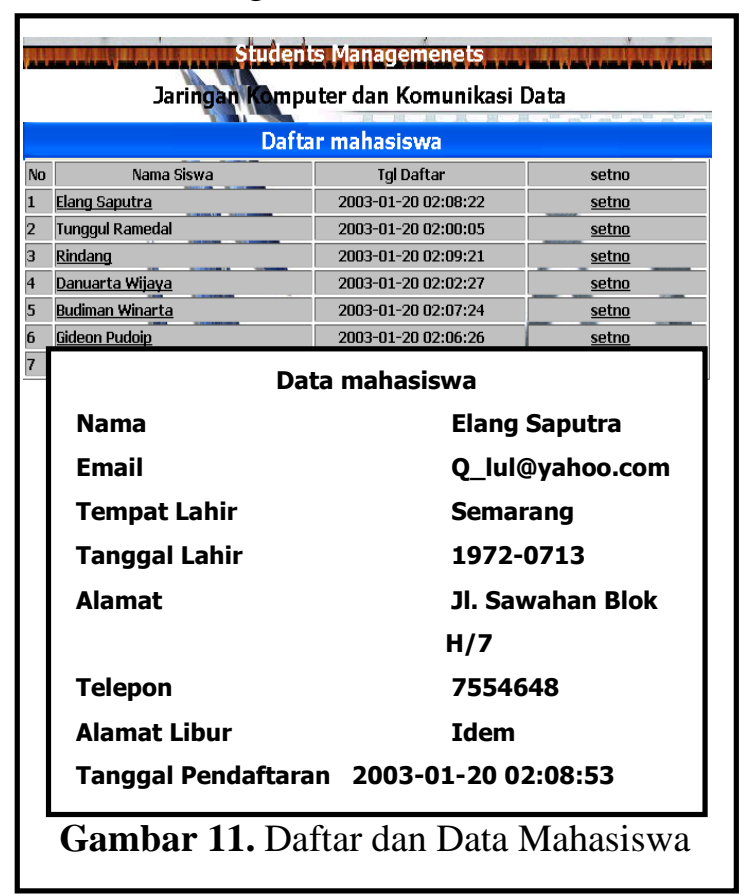

Di dalam halaman tersebut terdapat daftar mahasiswa serta status mahasiswa pada mata kuliah tersebut. Dosen juga dapat mengakses data personal mahasiswa yang mengikuti mata kuliahnya. Jika diperlukan dosen dapat mengubah status keaktifan mahasiswa dari aktif menjadi tidak aktif atau sebaliknya.

\section{Perancangan Administrator}

Prancangan untuk administrator sistem e-Learning pada dasarnya sama dengan dosen, tetapi mempunyai hak akses yang lebih banyak dibandingkan dengan dosen. Administrator berfungsi sebagai pengelola sistem secara keseluruhan. Administrator dapat melihat daftar dosen dan mahasiswa serta menentukan keaktifannya. Setiap anggota yang mempunyai status aktif akan dapat mengakses sistem, tetapi jika statusnya tidak aktif maka anggota tersebut akan dapat mengakses sistem.

Perancangan lain yang dimiliki oleh administrator adalah pembuatan polling atau jajak pendapat. Pembuatan polling ini hanya dimiliki oleh administrator sistem. Polling dapat ditujukan pada umum, dosen, atau mahasiswa. Polling ini digunakan untuk mengumpulkan informasi dan pendapat para pengguna mengenai suatu hal, misalnya Sistim e-Learning apakah sudah baik atau perlu ditingkat.

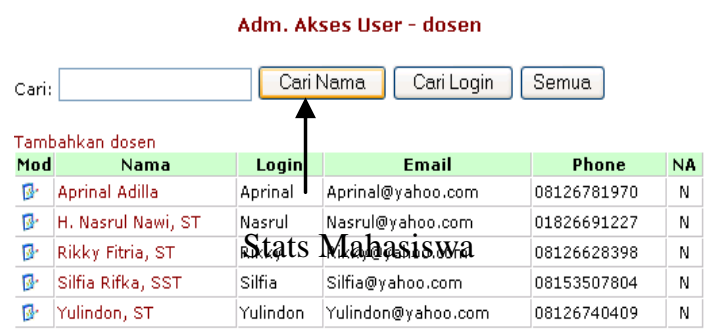

Gambar 12. Daftar Dosen Pada Sistim e-Learning

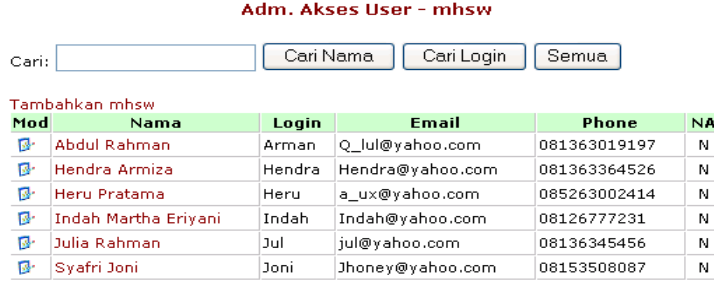

Gambar 13. Daftar Mahasiswa Pada Sistim e-Learning

\begin{tabular}{|r|l|l|}
\hline PoIIID & PollDate & \multicolumn{2}{|c|}{ Title } \\
\hline 1 & $\begin{array}{l}2005-06- \\
06\end{array}$ & Distro Linux Favorit \\
\hline 2 & $\begin{array}{l}2005-07- \\
23\end{array}$ & Bagai Mana Menurut anda e_learning berbasis Web? \\
\hline 3 & $\begin{array}{l}2005-08- \\
11\end{array}$ & $\begin{array}{l}\text { Siapakah Dosen favourite anda di Program Studi Tek } \\
\text { Gambar 14. Daftar Polling Pada Sistim } \\
\text { e-Learning }\end{array}$ \\
\hline
\end{tabular}

Pada sistem e_Learning ini Administrator juga dapat mengirim berita, dimana berita ini dapat ditujukan pada seluruh pengguna aplikasi sistem e_learning ini. Kita dapat melihat berita tersebut pada hyperlink daftar berita. 


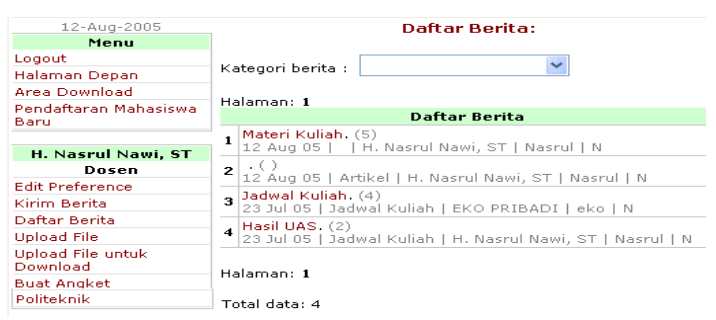

Gambar 15. Halaman Daftar Berita

\section{Perancangan Mahasiwa}

Pelajar atau mahasiswa yang terdaftar didalam Sistim e-Learning dapat mengakses beberapa aplikasi e-Learning. Mahasiswa dapat mengikuti suatu perkuliahan dengan cara mendaftarkan pada mata kuliah yang hendak diikutinya. Daftar mata kuliah yang ada didalm Sistim disajikan pada halaman catalog mata kuliah. Mahasiswa yang mengikuti mata kuliah dapat secara langsung mengakses mata kuliah terssebut.

Bagi mahasiswa yang terdaftar juga dapat mengakses daftar tugas dan daftar quiz tersebut disajikan menurut urutan tanggal pengiriman. Mahasiswa dapat mengumpulkan tugas melalui hyprlink reply pada daftar tugas dan quiz tersebut. Tugas dan quiz yang telah dikirimkan akan dicatat di dalam database dan akan dikirimkan pada halaman dosen. Mahasiswa yang telah mengikuti suatu mata kuliah juga dapat mengakses daftar nilai mata kuliah yang diikutinya.

Bagi mahasiswa yang terdaftar juga dapat mengakses kalender akademik, mengisi KRS, mengetahui Indeks Prtestasi, dan melakukan registrasi ulang mahasiswa.

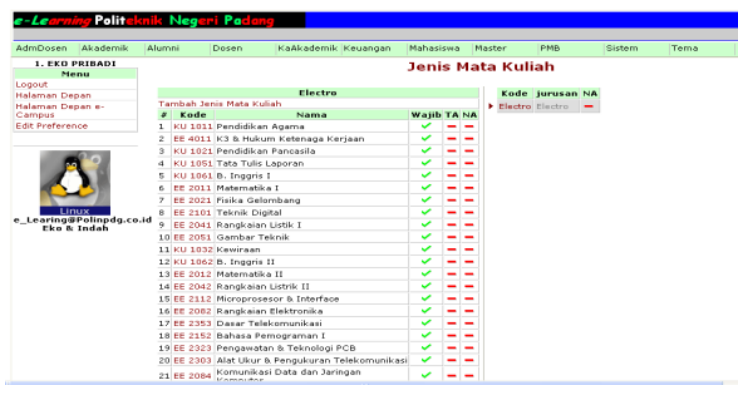

Gambar 16. Daftar Mata Kuliah Gambar

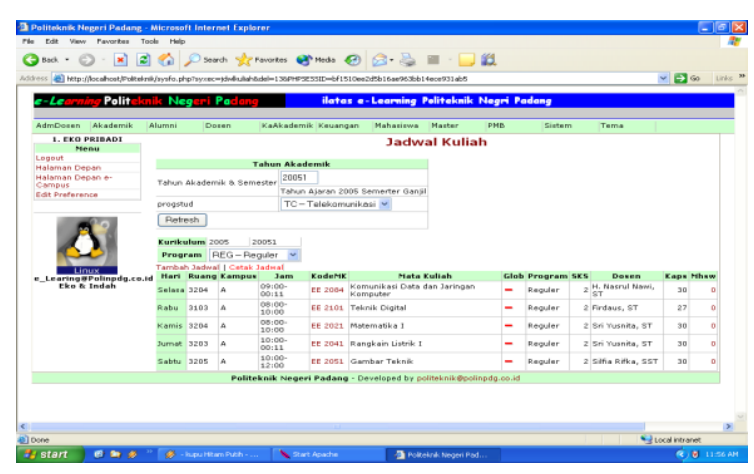

Gambar 17. Jadwal Kuliah Mahasiswa

Selain hal diatas mahasiswa juga dapat mengirimkan berita dan dapat mengisi polling yang diberikan, dan dapat juga mendownload file, melihat daftar berita dan mengirimkan berita.

\section{SIMPULAN}

Kesimpulan aplikasi e-Learning berbasis web bagi dosen ini adalah sebagai berikut :

1. Aplikasi e-Learning didesain sesuai dengan kebutuhan pengajar untuk mendukung aktivitas perkuliahan.

2. Aplikasi e-Learning yang telah dibuat dapat digunakan sebagai bahan masukan untuk membangun aplikasi baru atau memperbaiki aplikasi yang telah ada.

3. Dosen sebagai pengajar didalam perkuliahan membutuhkan layanan Sistim e-Learning yang memadai untuk mengelola dan melakukan administrasi materi dan mahasiswanya.

\section{SARAN}

Saran-saran bagi pengembang prototype aplikasi e-Learning ini adalah sebagai berikut :

1. Perancangan e-Learning yang telah jadi hendaknya diuji lebih detail mengenai reabilitas terhadap beban kerja yang sebenarnya untuk mendapatkan hasil pengujian yang lebih baik.

2. Aplikasi e-Learning ini masih menggunakan mode asynchronous yang masih kurang interaksinya dibandingkan dengan pembelajaran tradisional. 
Aplikasi dengan mode synchronous dapat ditambah untuk meningkatkan interaksi para pengguna.

DAFTAR PUSTAKA

Emgineering Outreach, Distance Education at a Glance, http: //www.uidaho.edu/eo/index.html.

Distance Learning Resource Network, What is Distance Education?, http: //www.dlrn.org/library/index.html

Sherry, L, Issue in Disntance Learning, International Journal of Educationnal Telecomunications, 1996

Saba, Farhad, Ph.D., Disntance education: An Introduction, Saba \& Associates, 2001 